\title{
Human papillomavirus is detected in transitional cell carcinoma arising in renal transplant recipients
}

Husain, Ehab; Prowse, David M.; Ktori, Elena; Shaikh, Taufiq; Yaqoob, Magdi; Junaid, Islam; Baithun, Suhail1

\begin{abstract}
Aims: We investigated the role of human papillomavirus (HPV) in the development of transitional cell carcinoma (TCC) arising in renal transplant recipients.

Methods: Genomic DNA was extracted from $10 \mu \mathrm{m}$ paraffin embedded sections of five TCCs arising in five renal transplant recipients using the QIAamp DNA mini kit according to the manufacturer's instructions. $\beta$-globin PCR was performed to test DNA adequacy. Samples were tested for the presence of HPV DNA by broad spectrum HPV PCR method using non-biotinylated SPF10 primers (SPF1A, SPF1B, SPF1C, SPF1D, SPF2B, SPF2D) which amplify a short 65 bp fragment. Positive bands were identified on a 3\% gel. Positive samples underwent a second HPV PCR and were amplified using biotinylated SPF10 primer set, which amplifies the same 65 bp region of the L1 open reading frame. INNO-LiPA line probe assay was then performed to genotype the samples which uses a reverse hybridisation principle.
\end{abstract}

Results::Four of five TCCs examined were positive for HPV. The high risk HPV16 was detected in three cases whereas in the fourth case an unclassifiable HPV genotype was present. In all DNA samples, $\beta$-globin amplification was successful.

Conclusions: Our results indicate that HPV and in particular HPV16 may play an aetiological role in the development of TCC in renal transplant patients.

\section{Introduction:}

Transitional cell carcinoma (TCC) is the commonest malignant neoplasm that arises from the epithelial lining of the urinary tract (1). The exact aetiology of TCC is not well established but there are several risk factors implicated in its pathogenesis such as cigarette smoking occupational carcinogens and analgesic abuse (2). The incidence 
of transitional cell carcinoma (TCC) in renal transplant recipients has been reported to be higher than the general population (3). However, the explanation of such observation is not clear.

Human papillomavirus (HPV) is a family of double stranded DNA viruses that are associated with the development of genital warts anogenital cancers and other epithelial lesions $(4,5)$. Within this family, there are specific high-risk HPV types with an established oncogenicity in cervical cancer and other anogenital cancers, in particular HPV 16, 18, 31, 33 and 35 (6, 7). The HPV viral oncogenic proteins E6 and E7 are responsible for perturbation of cell cycle and apoptosis regulators resulting in increased proliferation and finally immortalisation of infected epithelial cells (8).

The role of HPV in the development of TCC in the non-transplanted population is still controversial with conflicting reports in the literature. Many of the previous studies failed to find HPV in these tumours (9), whereas some others reported its detection in up- to $57 \%$ of cases (10).

We investigated the role of HPV in the development of TCC in renal transplant patients.

\section{Methods:}

We reviewed the records of 681 renal transplant recipients at Barts and the London hospitals between 1991 and 2005 and we found 6 patients who developed transitional cell carcinoma of the urinary tract after renal transplantation. Three tumours occurred in the transplanted ureter/kidney, 1 occurred in the native ureter and 2 in the bladder. The original H\&E stained slides were reviewed and new H\&E stained sections were taken from the paraffin blocks to confirm that tumour tissue is still present in the blocks. One case (bladder tumour) was excluded because no more tumour tissue was present in the block. Therefore, a total of 5 cases were included in our study. DNA was extracted from the paraffin embedded tissue, using QIAamp DNA Mini kit (Qiagen Cat No. 51304) according to manufacturers' instructions. Beta-Globin PCR was performed to test DNA adequacy. Primers B1 (sequence: 5'-GTG TGC TGG CCC ATC ACT TT-3') and B19 (sequence: 5'-CAA GAA AGC GAG CTT AGT GA-3') were used, yielding a PCR product of 120 base pairs which was visualized in a 3\% agarose gel containing ethidium bromide. After validating the presence of 
adequate DNA, samples were tested for the presence of HPV DNA by a broad spectrum HPV PCR method using non-biotinylated SPF10 primers (SPF1A, SPF1B, SPF1C, SPF1D, SPF2B and SPF2D) which amplify a short 65bp fragment of the L1 open reading frame (ORF). Positive bands were identified on a 3\% gel. INNO-LiPA line probe assay (Innogenetics) was then performed to genotype the samples using a reverse hybridization principle. HPV types detectable include high risk types 16,18 , $31,33,58,34,35,39,45,51,52,56,58,59,66$, 68, low risk types $6,11,40,42,43$, 44, 54, 74 and unclassified types 53 and $70(11,12)$.

\section{Results:}

Beta-Globin amplification was successful in all DNA samples. All 5 DNA samples showed a positive amplification signal of HPV using the SPF10 protocol although the signal was predominantely weak but was consistent on repetition. Using the LiPA line probe assay, four out of five TCCs examined were positive for HPV (light band in cases 1-4, figure 1). In three of these, HPV 16 was identified (dark band in cases 1,3 and 4, figure 1) and in the fourth case (case 2, figure 1) the type of HPV was unclassifiable.

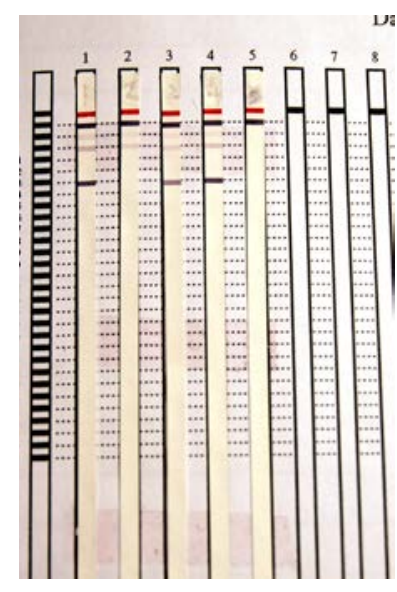

Figure 1: LiPA line probe assay showing HPV positivity.

\begin{tabular}{|l|l|l|l|}
\hline No & B-globin & SPF10 HPV PCR & LiPA \\
\hline 1 & + & HPV+ & HPV+: HPV 16 \\
\hline 2 & + & Weak HPV+ & HPV+: No genotypes \\
& & & identified on LiPA \\
\hline
\end{tabular}




\begin{tabular}{l|l|l|l}
\hline 3 & + & Weak HPV & HPV+: HPV 16 \\
\hline 4 & Faintly + & HPV + & HPV+: HPV 16 \\
\hline 5 & + & Weak HPV+ & HPV- \\
\multicolumn{2}{l}{ Table 1: Results of PCR analyses and corresponding LiPA findings. }
\end{tabular}

\section{Discussion:}

There is a large discrepancy between the previously published studies with regard to the incidence of HPV detection in TCCs. Many failed to detect HPV DNA in any of their cases (13-15). This is in agreement with our findings in an earlier study where we examined 78 TCCs for the presence of HPV DNA using PCR and no amplification of viral DNA was detected in any of our cases (16). In the studies that succeeded to detect the presence of the virus in tumour tissue, the rate of HPV DNA detection in TCC in non-transplanted patients ranged from 3\% (17) to 57\% (10). This marked variation has been explained by technical (18) (i.e. tissue fixation, DNA preparation and amplification conditions) and geographical differences (16) (with higher frequencies of HPV detection in Asia and Southern Europe compared to lower rates of detection in Northern Europe and America). It is quite interesting to note that the only case of HPV positive TCC in the study of Muvula and colleagues was in a female patient who had an invasive cervical squamous cell carcinoma which was also positive for HPV 16 (17). This may be related to the anatomical relations and the communication between the urinary bladder and the mucosal surface of the female genital tract predisposing to transmission of infection.

The amplification of Beta-Globin indicates that the extracted DNA was adequate for PCR purposes. In addition, the consistently positive HPV amplification on repetition shows that our results are genuine.

In the current study, the major HPV type identified was the high risk HPV 16 in 3 cases and in the fourth positive case HPV typing was unclassified. Reviewing the literature, HPV 16 was the commonest HPV type to be detected in TCC $(19,20)$. In the study of LaRue and colleagues it was detected in 27 out of 28 positive TCCs (18). HPV 16 and/or 18 were the most common HPV types (50\% of cases were positive) to 
be detected in TCCs obtained from immunocompetent patients in the study of Agliano et al. (21).

Only one report was found in the literature concerning the presence of HPV type 11 in a urinary bladder carcinoma arising in a renal transplants recipient (22). In the setting of immunodeficiency, HPV type 16 was detected in one case of bladder TCC, whereas non of the TCCs obtained from immunocompetent patients contained the virus (23). It appears that the immunosuppressive therapy favours the persistence of HPV infection and predisposes to carcinogenesis of TCC in transplant patients.

To our knowledge this is the first work that includes TCCs arising in the upper urinary tract in the context of renal transplantation and proves the association between TCC development and HPV infection.

\section{Conclusion:}

Our results indicate that HPV and in particular the high risk HPV 16 may play an aetiological role in the development of TCC in the renal transplant patients.

\section{References:}

1. Leppert JT, Shvarts O, Kawaoka K, Lieberman R, Belldegrun AS, Pantuck AJ. Prevention of bladder cancer: a review. Eur Urol 2006;49(2):226-34.

2. Kirkali Z, Tuzel E. Transitional cell carcinoma of the ureter and renal pelvis. Crit Rev Oncol Hematol 2003;47(2):155-69.

3. Kao YL, Ou YC, Yang CR, Ho HC, Su CK, Shu KH. Transitional cell carcinoma in renal transplant recipients. World J Surg 2003;27(8):912-6.

4. Parkin DM, Bray F. Chapter 2: The burden of HPV-related cancers. Vaccine 2006;24 Suppl 3:S11-25.

5. Partridge JM, Koutsky LA. Genital human papillomavirus infection in men. Lancet Infect Dis 2006;6(1):21-31.

6. Keating JT, Cviko A, Riethdorf S, Riethdorf L, Quade BJ, Sun D, et al. Ki-67, cyclin E, and p16INK4 are complimentary surrogate biomarkers for human papilloma virus-related cervical neoplasia. Am J Surg Pathol 2001;25(7):884-91.

7. van der Graaf Y, Molijn A, Doornewaard H, Quint W, van Doorn LJ, van den Tweel J. Human papillomavirus and the long-term risk of cervical neoplasia. Am J Epidemiol 2002;156(2):158-64.

8. Walboomers JM, Jacobs MV, Manos MM, Bosch FX, Kummer JA, Shah KV, et al. Human papillomavirus is a necessary cause of invasive cervical cancer worldwide. J Pathol 1999;189(1):12-9. 
9. Sur M, Cooper K, Allard U. Investigation of human papillomavirus in transitional cell carcinomas of the urinary bladder in South Africa. Pathology 2001;33(1):17-20.

10. Kamel D, Paakko P, Pollanen R, Vahakangas K, Lehto VP, Soini Y. Human papillomavirus DNA and abnormal p53 expression in carcinoma of the urinary bladder. Apmis 1995;103(5):331-8.

11. Kleter B, van Doorn LJ, Schrauwen L, Molijn A, Sastrowijoto S, ter Schegget J, et al. Development and clinical evaluation of a highly sensitive PCR-reverse hybridization line probe assay for detection and identification of anogenital human papillomavirus. J Clin Microbiol 1999;37(8):2508-17.

12. Doorbar J. Molecular biology of human papillomavirus infection and cervical cancer. Clin Sci (Lond) 2006;110(5):525-41.

13. Saltzstein DR, Orihuela E, Kocurek JN, Payne DA, Chan TS, Tyring SK. Failure of the polymerase chain reaction (PCR) to detect human papilloma virus (HPV) in transitional cell carcinoma of the bladder. Anticancer Res 1993;13(2):423-5. 14. Aynaud O, Tranbaloc P, Orth G. Lack of evidence for a role of human papillomaviruses in transitional cell carcinoma of the bladder. J Urol 1998;159(1):869; discussion 90.

15. Sano T, Sakurai S, Fukuda T, Nakajima T. Unsuccessful effort to detect human papillomavirus DNA in urinary bladder cancers by the polymerase chain reaction and in situ hybridization. Pathol Int 1995;45(7):506-12.

16. Youshya S, Purdie K, Breuer J, Proby C, Sheaf MT, Oliver RT, et al. Does human papillomavirus play a role in the development of bladder transitional cell carcinoma? A comparison of PCR and immunohistochemical analysis. J Clin Pathol 2005;58(2):207-10.

17. Mvula M, Iwasaka T, Iguchi A, Nakamura S, Masaki Z, Sugimori H. Do human papillomaviruses have a role in the pathogenesis of bladder carcinoma? J Urol 1996;155(2):471-4.

18. LaRue H, Simoneau M, Fradet Y. Human papillomavirus in transitional cell carcinoma of the urinary bladder. Clin Cancer Res 1995;1(4):435-40.

19. Lopez-Beltran A, Escudero AL, Vicioso L, Munoz E, Carrasco JC. Human papillomavirus DNA as a factor determining the survival of bladder cancer patients. Br J Cancer 1996;73(1):124-7.

20. Smetana Z, Keller T, Leventon-Kriss S, Huszar M, Lindner A, MitraniRosenbaum S, et al. Presence of human papilloma virus in transitional cell carcinoma in Jewish population in Israel. Cell Mol Biol (Noisy-le-grand) 1995;41(8):1017-23. 21. Agliano AM, Gradilone A, Gazzaniga P, Napolitano M, Vercillo R, Albonici L, et al. High frequency of human papillomavirus detection in urinary bladder cancer. Urol Int 1994;53(3):125-9.

22. Querci della Rovere G, Oliver RT, McCance DJ, Castro JE. Development of bladder tumour containing HPV type 11 DNA after renal transplantation. Br J Urol 1988;62(1):36-8.

23. Kitamura T, Yogo Y, Ueki T, Murakami S, Aso Y. Presence of human papillomavirus type 16 genome in bladder carcinoma in situ of a patient with mild immunodeficiency. Cancer Res 1988;48(24 Pt 1):7207-11. 